OPEN ACCESS

Edited by:

Artur Summerfield,

Institute of Virology and Immunology,

Switzerland

Reviewed by: Alejandro Ramirez, Iowa State University, United States Caroline Duchaine,

Laval University, Canada

*Correspondence:

Benjamin D. Anderson benjamin.anderson2@duke.edu

Specialty section: This article was submitted to Veterinary Infectious Diseases, a section of the journal Frontiers in Veterinary Science

Received: 25 April 2017 Accepted: 10 July 2017

Published: 27 July 2017

Citation:

Anderson BD, Lednicky JA, Torremorell M and Gray GC (2017) The Use of Bioaerosol Sampling for Airborne Virus Surveillance in Swine Production Facilities: A Mini Review.

Front. Vet. Sci. 4:121. doi: 10.3389/fvets.2017.00121

\section{The Use of Bioaerosol Sampling for Airborne Virus Surveillance in Swine Production Facilities: A Mini Review}

\author{
Benjamin D. Anderson ${ }^{1,2 *}$, John A. Lednicky ${ }^{2}$, Montserrat Torremore/ ${ }^{3}$ \\ and Gregory C. Gray ${ }^{1}$
}

\begin{abstract}
'Division of Infectious Diseases, School of Medicine, Global Health Institute, Duke University, Durham, NC, United States, ${ }^{2}$ Department of Environmental and Global Health, College of Public Health \& Health Professions, Emerging Pathogens Institute, University of Florida, Gainesville, FL, United States, ${ }^{3}$ Department of Veterinary Population Medicine, College of Veterinary Medicine, University of Minnesota-Twin Cities, Saint Paul, MN, United States
\end{abstract}

Modern swine production facilities typically house dense populations of pigs and may harbor a variety of potentially zoonotic viruses that can pass from one pig generation to another and periodically infect human caretakers. Bioaerosol sampling is a common technique that has been used to conduct microbial risk assessments in swine production, and other similar settings, for a number of years. However, much of this work seems to have been focused on the detection of non-viral microbial agents (i.e., bacteria, fungi, endotoxins, etc.), and efforts to detect viral aerosols in pig farms seem sparse. Data generated by such studies would be particularly useful for assessments of virus transmission and ecology. Here, we summarize the results of a literature review conducted to identify published articles related to bioaerosol generation and detection within swine production facilities, with a focus on airborne viruses. We identified 73 scientific reports, published between 1991 and 2017, which were included in this review. Of these, 19 (26.7\%) used sampling methodology for the detection of viruses. Our findings show that bioaerosol sampling methodologies in swine production settings have predominately focused on the detection of bacteria and fungi, with no apparent standardization between different approaches. Information, specifically regarding virus aerosol burden in swine production settings, appears to be limited. However, the number of viral aerosol studies has markedly increased in the past 5 years. With the advent of new sampling technologies and improved diagnostics, viral bioaerosol sampling could be a promising way to conduct non-invasive viral surveillance among swine farms.

Keywords: bioaerosols, viruses, swine, animal production, zoonoses, air sampling

\section{INTRODUCTION}

Bioaerosols can be defined as fine particles ranging in size and composition that are suspended in the air and considered to be derived from a biological source or to affect a biological target (1). Such particles can contain or consist of bacteria, fungi, organic and inorganic particulates, toxins, and viruses. Considerable research has been conducted to understand how bioaerosols impact human health in both indoor and outdoor settings, with a particular emphasis on occupational exposures $(2-7)$. With the intensification of animal production over the past 30 years, and the rise of farms housing large number of animals, bioaerosols have become a particular concern to the health of other animals, workers, and the communities located near such facilities (8). There have been efforts 
directed at evaluating these bioaerosol risks (9-17), though data related specifically to the detection of airborne viruses still remain largely limited. Most studies have instead focused their sampling strategies on bacteria, fungi, particulates, and endotoxins. This lack of targeted virus sampling is worrisome given that the airborne transmission pathway has been identified as important to the movement of viruses in and between production facilities $(18,19)$. As such, methodologies that fully assess the risks of bioaerosol exposures in animal production facilities are important for the design and implementation of effective interventions to mitigate the exposure risks to humans and animals in the surrounding environment.

This literature review was conducted to better understand the source and types of viral bioaerosols within and around swine production facilities, the scope of sampling methodologies, and the current state of research. The information summarized from this review may also serve as a collated resource for other researchers.

\section{MATERIALS AND METHODS}

\section{Search Strategy and Selection Criteria}

Following PRISMA guidelines, a systematic online search of three scientific abstract indexing databases (PubMed, Web of Science, and $\mathrm{CAB}$ Abstracts), with no restriction on year of publication, was performed using the following structured query: (bioaerosol ${ }^{*}$ or bio-aerosol ${ }^{\star}$ ) and (swine or pig ${ }^{\star}$ or hog ${ }^{\star}$ or barrow ${ }^{\star}$ or gilt ${ }^{\star}$ or sow or sows or boar or boars or porcine or pork or suidae or sus scrofa). Given that PubMed is a database specific to biomedical and life science research, Web of Science and CAB Abstract databases were included to capture a broader range of disciplines and information sources, including engineering, agriculture, and other technical journals. Search results were manually reviewed and abstracts meeting the following inclusion criteria were retained: (1) peer-reviewed and published scientific report, (2) research occurred in an experimental swine unit, swine production facility, or market, and (3) a bioaerosol sampling strategy was utilized. Articles that were reviews, comments to editor, perspectives, personal opinions, did not present sampling result data, did not have a full-text article available in English, or did not meet the inclusion criteria listed above were excluded. Full reports were reviewed and summarized according to their date of publication.

\section{RESULTS}

\section{Search Results and Study Selection}

From a search conducted April 5,2017, results yielded 68 publications from PubMed, 180 publications from Web of Science, and 90 publications from CAB Abstracts. After 128 duplicates were removed, 210 publications remained. These were screened, and 114 articles that did not meet the initial inclusion criteria were removed leaving 96 articles. Finally, 23 full-text articles that did not present sufficient data, were not available in English, or did not sufficiently describe the methods were also removed, resulting in a final article count of 73 (Figure S1 in Supplementary Material).

\section{Study Characteristics}

After the selection and screening procedures were completed, 73 scientific reports that met the inclusion criteria for this review remained (Table S1 in Supplementary Material) (19-91). Articles were published between 1991 and 2017 (Figure S2 in Supplementary Material). Only 8 of $73(11.0 \%)$ articles were published in the 1990s (20-27), whereas 40 of 73 (54.8\%) have been published since the beginning of 2010 (52-91). Of the 73 reviewed articles, 41 (56.2\%) included methodologies to evaluate bacteria, $25(34.2 \%)$ to evaluate fungi, $19(26.0 \%)$ to evaluate viruses, $16(21.9 \%)$ to evaluate dust and particulates, $11(15.1 \%)$ to evaluate endotoxins, $8(11.0 \%)$ to evaluate gases, $6(8.2 \%)$ to evaluate $16 \mathrm{~s}$ rRNA genes, $3(4.1 \%)$ each to evaluate antibiotic resistance and organic compounds, and 1 (1.4\%) each to evaluate archaea and chemical markers (Table S2 in Supplementary Material). Studies were conducted in the United States $(n=35)$, Canada $(n=9)$, Republic of Korea $(n=8)$, China $(n=4)$, Denmark $(n=4)$, Poland $(n=4)$, Germany $(n=3)$, Australia $(n=2)$, The Netherlands $(n=2)$, Belgium $(n=1)$, Portugal $(n=1)$, Sweden $(n=1)$, Switzerland $(n=1)$, and the United Kingdom $(n=1)$. Primary bioaerosol sampling methodologies utilized across the studies included a single, two- and six-stage Andersen sampler, all-glass impingers, button sampler, various filter collection cassettes in combination with molecular sequencing and mass spectrometry, slit sampler, and liquid cyclonic collector.

\section{DISCUSSION}

In this literature review, articles were searched and summarized to better understand the source and types of bioaerosols detected in and around swine production facilities, as well as the sampling methods used to detect them. Based on the articles evaluated, different bacteria were the predominantly sampled bioaerosol targets, with several studies identifying elevated levels of both Gram-positive and Gram-negative bacteria, including Actinobacillus pleuropneumoniae, Escherichia coli, Staphylococcus aureus, and Streptococcus suis, among others. Antibiotic resistance among detected bacterial pathogens was also assessed in several studies, which found a high rate of antibiotic-resistant bacteria both within and downwind from swine production facilities $(35,40,81)$. Gibbs et al. found that antibiotic-resistant microbes were detectable at least $150 \mathrm{~m}$ downwind from the sampled swine barn at concentrations that could pose a threat to individuals working in the barns, as well as those living within close proximity (40). Arfken et al. found that fecal spray fields using swine feces as fertilizer could be a source of aerosolization and introduction of antibiotic-resistant bacteria into the environment (81).

Seasonal variation was assessed in multiple studies identifying trends in the rates of bioaerosol detection between seasons, which also varied based on the type of target being sampled $(21,44,46$, $51,77)$. Kim et al. found that fungal spores were more likely to be detected during the warmer summer months, whereas bacteria and particulates were found at higher concentrations during the winter (44). Anderson et al. compared detections of influenza A virus (IAV) RNA between summer and winter, finding an association between an increased detection rate during the winter and temperatures below $20^{\circ} \mathrm{C}(85)$. 
One of the first studies to assess bioaerosol transmission of viruses between swine was conducted in 1997 by Torremorell et al., which evaluated the airborne transmission of porcine reproductive and respiratory syndrome virus (PRRSV) under experimental conditions among nursery pigs (25). In this study, the authors documented short-distance airborne transmission of PRRSV and found that transmission was strain dependent. Otake et al. then conducted a study in 2002 which also evaluated the propensity of PRRSV to be transmitted by aerosol, but this time under field conditions (19). Results demonstrated that naive pigs with direct or indirect contact with PRRSV-infected pigs also became infected, while sentinel pigs placed 1 and $30 \mathrm{~m}$ away from exhaust fans of the barn containing the infected pigs did not. Four years later in 2006, Hermann et al. carried out an optimization study using an all-glass impinger for the detection of PRRSV and IAV under experimental conditions (92). The study ultimately concluded that given the lack of standard methodology for isolating certain pathogens in aerosols, future methods should be individually optimized and validated for each pathogen of interest.

These seminal works were followed by 16 additional studies $(47,50,55,56,61,63-65,71,74,75,80,82,85,87,88,90)$ between 2009 and 2017, which found detectable levels of viral RNA from aerosolized PRRSV, IAV, porcine epidemic diarrhea virus (PEDV), and porcine circovirus type 2 (PCV2) (Table 1). These studies were either experimental or field based in their design and varied greatly in their research objectives, including the evaluation of collection efficiencies for different sampling devices, estimating the burden of aerosolized viruses, and evaluating the efficiency of air cleaning systems or other similar interventions aimed at reducing bioaerosols in pig facilities. Notably, the experimental studies appeared to benefit greatly from inclusion of more robust controls in their assessment, while the field-based studies seemed to be able to better address the questions of transmission risk associated with bioaerosol generation in actual production farms. Given the lack of standardized methodology and the diversity in study designs, it is difficult to make direct comparisons between studies. Such standardization would be essential to verify the consistency and reproducibility of bioaerosol detection results across studies. Furthermore, it would be useful for future aerosol detection studies to incorporate more comprehensive epidemiological approaches to better ascertain the association between human, animal, and environmental risk factors with aerosolization of target viruses. These epidemiological approaches should include larger sample sizes, appropriate controls, and a prospective sampling strategy.

Several studies have documented detection of PRRSV, IAV, and PEDV virus genomic RNAs at various distances downwind from swine barns with infected source populations (47, 50, $55,63,71)$. PEDV RNA was detected up to $16.1 \mathrm{~km}$ (71) away, PRRSV RNA up to $9.1 \mathrm{~km}(47,50,55)$ away, and IAV up to $2.1 \mathrm{~km}$ (75) downwind from infected source populations (Figure 1). Furthermore, PRRSV was shown to be infectious $120 \mathrm{~m}$ and $4.7 \mathrm{~km}$ away from an infected herd $(47,50)$. These findings suggest that viral bioaerosols could pose a potential risk to other farms and their livestock, or communities located within close proximity to barns with infected pigs, which may undermine current biosecurity practices.
TABLE 1 | Evaluation of reviewed bioaerosol studies assessing viruses $(n=19)$.

\begin{tabular}{|c|c|c|}
\hline Reference & Target virus(es) & Strength(s) \\
\hline $\begin{array}{l}\text { Torremorell } \\
\text { et al. ( } 25)\end{array}$ & $\begin{array}{l}\text { Porcine } \\
\text { reproductive } \\
\text { and respiratory } \\
\text { syndrome virus } \\
\text { (PRRSV) }\end{array}$ & $\begin{array}{l}\text { - Evaluated virus viability } \\
\text { - Confirmation of source population } \\
\text { infection using virus isolation and } \\
\text { serology } \\
\text { - Assessed strain differences } \\
\text { - Robust controls }\end{array}$ \\
\hline Otake et al. (19) & PRRSV & $\begin{array}{l}\text { - Evaluated virus viability } \\
\text { - Confirmation of source population } \\
\text { infection using virus isolation and } \\
\text { serology } \\
\text { - Assessed strain differences } \\
\text { - Robust controls } \\
\text { - Evaluated long-distance transport }\end{array}$ \\
\hline Pitkin et al. (50) & PRRSV & $\begin{array}{l}\text { - Evaluated virus viability } \\
\text { - Confirmation of source population } \\
\text { infection } \\
\text { - Robust sampling strategy } \\
\text { - Year-long sampling }\end{array}$ \\
\hline Dee et al. (47) & PRRSV & $\begin{array}{l}\text { - Evaluated virus viability } \\
\text { - Confirmation of source population } \\
\text { infection } \\
\text { - Robust controls } \\
\text { - Evaluated long-distance transport }\end{array}$ \\
\hline Otake et al. (55) & PRRSV & $\begin{array}{l}\text { - Evaluated virus viability } \\
\text { - Confirmation of source population } \\
\text { infection } \\
\text { - Robust controls } \\
\text { - Evaluated long-distance transport }\end{array}$ \\
\hline Verreault et al. (56) & $\begin{array}{l}\text { Porcine } \\
\text { circovirus type } 2 \\
\text { (PCV2) }\end{array}$ & $\begin{array}{l}\text { - Multi-year sampling } \\
\text { - Sensitivity of detection assay explored }\end{array}$ \\
\hline Linhares et al. (61) & PRRSV & $\begin{array}{l}\text { - Evaluated virus viability } \\
\text { - Confirmation of source population } \\
\text { infection } \\
\text { - Robust controls } \\
\text { - Pigs sampled concomitantly with air }\end{array}$ \\
\hline Corzo et al. (63) & $\begin{array}{l}\text { Influenza A virus } \\
\text { (IAV) }\end{array}$ & $\begin{array}{l}\text { - Evaluated virus viability } \\
\text { - Confirmation of source population } \\
\text { infection } \\
\text { - Subtyping conducted } \\
\text { - Evaluated long-distance transport }\end{array}$ \\
\hline Corzo et al. (64) & IAV & $\begin{array}{l}\text { Bioaerosol detection and viral } \\
\text { secretion in pigs directly compared }\end{array}$ \\
\hline $\begin{array}{l}\text { de Evgrafov } \\
\text { et al. (65) }\end{array}$ & PCV2 & $\begin{array}{l}\text { - Used controls to rule out } \\
\text { contamination } \\
\text { - Used advanced genomic methods }\end{array}$ \\
\hline Alonso et al. (71) & $\begin{array}{l}\text { Porcine epidemic } \\
\text { diarrhea virus } \\
\text { (PEDV) }\end{array}$ & $\begin{array}{l}\text { - Evaluated virus viability } \\
\text { - Confirmation of source population } \\
\text { infection } \\
\text { - Evaluated long-distance transport }\end{array}$ \\
\hline Brito et al. (74) & PRRSV & $\begin{array}{l}\text { - Used controls to rule out } \\
\text { contamination } \\
\text { - Used GIS modeling to correlate } \\
\text { sampling with farm density } \\
\text { - Used sequencing techniques and } \\
\text { phylogenetic analysis }\end{array}$ \\
\hline Corzo et al. (75) & $\mathrm{IAV}$ & $\begin{array}{l}\text { - Evaluated virus viability } \\
\text { - Confirmation of source population } \\
\text { infection } \\
\text { - Robust controls } \\
\text { - Viral shedding assessed over time }\end{array}$ \\
\hline
\end{tabular}

(Continued) 
TABLE 1 | Continued

\begin{tabular}{|c|c|c|}
\hline Reference & Target virus(es) & Strength(s) \\
\hline Alonso et al. (80) & $\begin{array}{l}\text { IAV } \\
\text { PRRSV } \\
\text { PEDV }\end{array}$ & $\begin{array}{l}\text { - Multiple viruses concomitantly } \\
\text { - Particle size evaluated } \\
\text { - Evaluated virus viability } \\
\text { - Confirmation of source population } \\
\text { infection } \\
\text { - Robust controls } \\
\text { - Pigs sampled concomitantly with air } \\
\text { - Infectivity of air samples assessed } \\
\text { using swine bioassay }\end{array}$ \\
\hline Choi et al. (82) & IAV & $\begin{array}{l}\text { - Human, animal, and environmental } \\
\text { sampling conducted concomitantly } \\
\text { - Evaluated virus viability } \\
\text { - Documented possible aerosol } \\
\text { transmission of swine-sourced virus } \\
\text { to humans } \\
\text { - Sequencing used to compare } \\
\text { detected virus RNA gene segments }\end{array}$ \\
\hline $\begin{array}{l}\text { Anderson } \\
\text { et al. (85) }\end{array}$ & IAV & $\begin{array}{l}\text { - Human, animal, and environmental } \\
\text { - Sampling conducted concomitantly } \\
\text { - Risk factors evaluated } \\
\text { - Sampling types statistically compared }\end{array}$ \\
\hline Neira et al. (87) & IAV & $\begin{array}{l}\text { - Sampling captured during outbreaks } \\
\text { under field settings } \\
\text { - Animal, environmental, and air } \\
\text { sampling conducted concomitantly } \\
\text { - Evaluated virus viability } \\
\text { - Sampling types statistically compared }\end{array}$ \\
\hline $\begin{array}{l}\text { O'Brien and } \\
\text { Nonnenmann (88) }\end{array}$ & IAV & $\begin{array}{l}\text { - Human exposure directly assessed } \\
\text { - Two samplers compared } \\
\text { - Confirmation of source population } \\
\text { infection } \\
\text { - Physical conditions of farms assessed }\end{array}$ \\
\hline Alonso et al. (90) & $\begin{array}{l}\text { PRRSV } \\
\text { PEDV }\end{array}$ & $\begin{array}{l}\text { - Particle size evaluated } \\
\text { - Confirmation of source population } \\
\text { infection } \\
\text { - Sampling types statistically compared }\end{array}$ \\
\hline
\end{tabular}

Despite the increase in the number of studies that have been conducted using bioaerosol sampling for the detection of viruses, such approaches may have some limitations given the difficulty of determining the correct sampling parameters (i.e., flow rate, collection media, volume, etc.). Optimization is essential to capture aerosolized viruses and to maintain their viability throughout the collection process. Identifying viable virus is important because it allows for a more informed risk assessment in the environments being sampled. A viable virus carries a greater transmission risk to exposed humans or animals. In contrast, if the virus is already inactivated (by UV light or drying or other means) when it is detected, it likely poses minimal risk in terms of airborne transmission. This emphasizes the need for additional field-based studies that focus on the optimization of collection parameters to improve the recovery of viable virus.

Another important factor that contributes to the viability of aerosolized viruses is particle size. In a study conducted by Zuo et al., the authors demonstrated a close relationship between particle size of three different animal viruses (gastroenteritis virus, swine IAV, and avian IAV) and the infectivity and survivability of those viruses after collection using a bioaerosol sampling device (93). Though there were some differences between the three viruses tested, in general it was shown that the larger particle sizes (300-450 nm) had a higher survivability compared to particles measuring closer to the actual size of the virions (100-200 nm). Similarly, Alonso et al. found in their 2015 study that the viability of IAV and PRRSV was particle size dependent, only being able to isolate viable virus from particles larger than $2.1 \mu \mathrm{m}(80)$. Given this preliminary association, which is still not fully defined, future viral bioaerosol sampling studies would benefit from the routine inclusion of methodology to evaluate particle size as it relates to viability. Only a few studies in this review incorporated such an approach, however, this is likely due to limitations in the detection technology.

A further challenge to using bioaerosol sampling as a method for virus surveillance and risk assessment is that commercially available air samplers are not optimally designed for the collection of submicron particles $(<1 \mu \mathrm{m})$, for which the collection efficiencies tend to be low. Samplers are instead designed for the collection of micrometer-sized particles such as fungal spores and bacteria $(94,95)$. Using an experimental model, Hogan et al. evaluated collection efficiencies for three bioaerosol samplers (AGI-30, the SKC BioSampler and a frit bubbler), and found the collection efficiency for bacteriophages MS2 $(d=27.5 \mathrm{~nm})$ and T3 ( $d=45 \mathrm{~nm}$ ) to be extremely low (5-10\%) (96). Though conducted under a controlled setting, these findings indicate the collection efficiency for viruses to be markedly lower compared to that of larger bacteria and fungi in aerosols, which are often recovered at close to $100 \%$ efficiency. Despite these limitations, new optimization studies of different bioaerosol sampling devices have shown some promise in overcoming the challenge of low detection efficiency for some swine viruses $(63,64,75$, 82). Noteworthy, is a recent study conducted by Pan et al. which demonstrated a $93 \%$ recovery of aerosolized bacteriophage MS2 (2-5 $\mu \mathrm{m}$ in diameter) using a novel growth tube collector (GTC) (97). A subsequent study conducted by Lednicky et al. evaluated the same GTC sampling device with IAV, and demonstrated an $84 \%$ collection efficiency (98). These studies highlight how improvements in the sampling technology may continue to increase the sensitivity of viral bioaerosol sampling.

Overall, the bioaerosol sampling research studies evaluated in this review were predominately focused on the detection of bacteria and fungi and relied on broad-spectrum microbial detection as an indicator for overall bioaerosol burden. In addition, sampling strategies were found to utilize a wide variety of methodologies, with no apparent consistency between research groups, suggesting a lack of standard methods for performing bioaerosol studies in swine production settings. Many of the researchers in the reviewed studies agreed that there are insufficient data regarding virus aerosol burdens in swine production facilities to assess their potential impact upon human and animal health. Furthermore, only a few studies have since been conducted using multi-faceted strategies to sample animals, humans, and the environment. This approach will be critical in future studies to better understand transmission pathways and virus ecology. Finally, only one study was conducted in Mainland China, a region with the largest and fastest growing swine industry in the world (85). 


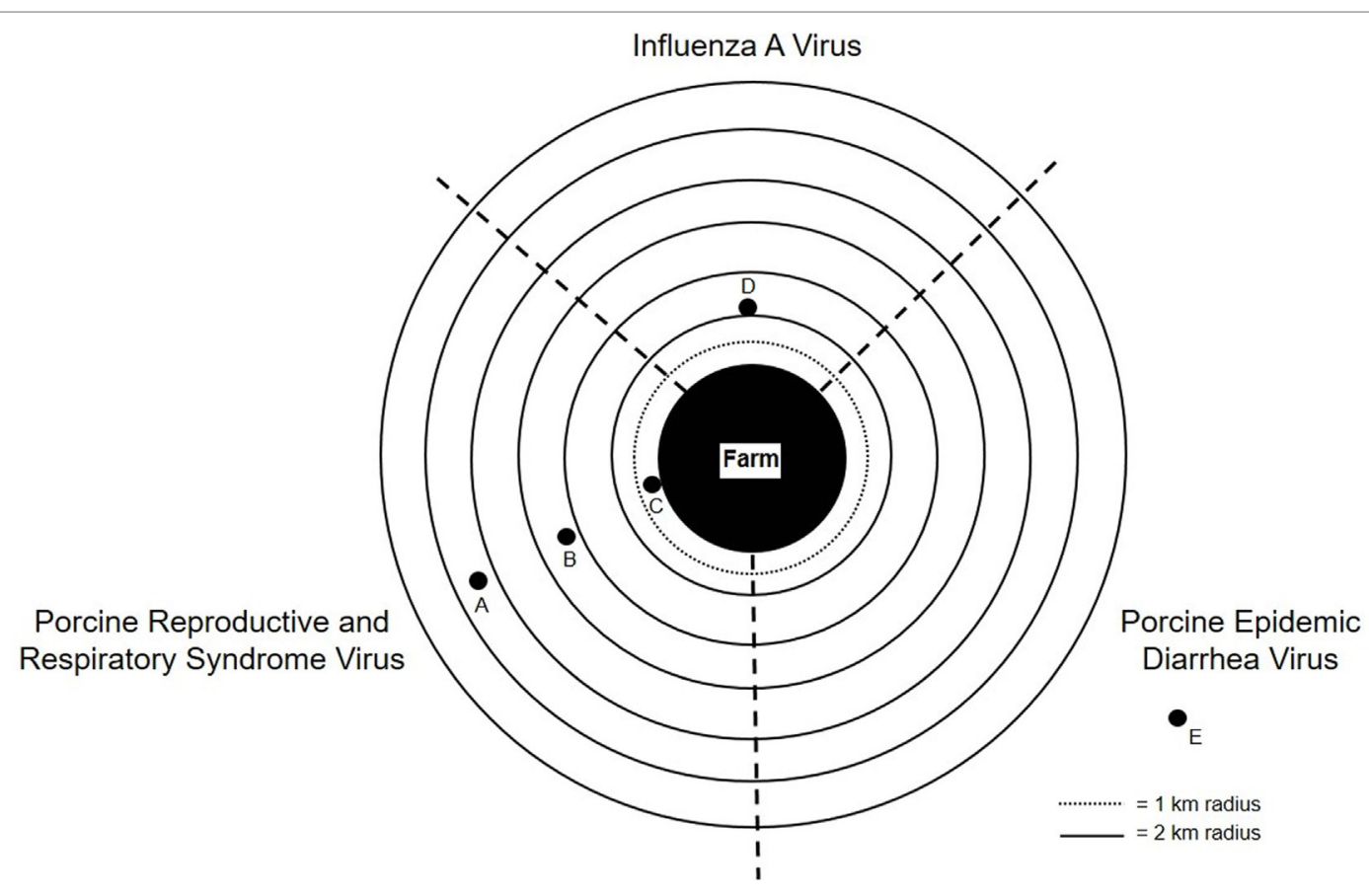

FIGURE 1 | Graphical depiction of influenza A virus (IAV), porcine reproductive and respiratory syndrome virus (PRRSV), and porcine epidemic diarrhea virus (PEDV) RNA detection downwind from farms with infected source populations: (A) PRRSV RNA detected up to $9.1 \mathrm{~km}$ away from infected source population; (B) PRRSV RNA detected $4.7 \mathrm{~km}$ away from infected source population; (C) PRRSV infects naïve pigs $120 \mathrm{~m}$ away from infected source population; (D) IAV RNA detected up to $2.1 \mathrm{~km}$ away from infected source population; and (E) PEDV RNA detected up to $16.1 \mathrm{~km}$ away from infected source population.

Recent breaches in animal production biosecurity in the United States, resulting in the incursion of H5N2 avian IAV $(99,100)$, as well as outbreaks of H3N2v IAV of swine origin in swine shows (101) and experimental challenge studies (75), suggest that virus aerosol transmission may play a much larger role in zoonotic disease transmission between pigs and from pigs to people. Infectious diseases, which affect the swine production industry, particularly PRRSV, may be further exacerbated by the dissemination of aerosolized viruses. As such, the further development and optimization of bioaerosol sampling technology seems prudent, as this review suggests bioaerosol sampling is a promising way to conduct non-invasive viral surveillance among swine farms and perhaps other, similar ecological settings.

\section{AUTHOR CONTRIBUTIONS}

BA conducted the literature review and wrote the manuscript; JL and MT helped revise the manuscript to add important scientific content and refine the interpretation of the results; GG conceived of the idea of the review and helped revise the manuscript to add important scientific content and refine the interpretation

\section{REFERENCES}

1. Cox CS, Wathes CM. Bioaerosols Handbook. Boca Raton: Lewis Publishers (1995). 623 p.

2. Burge H. Bioaerosols: prevalence and health effects in the indoor environment. JAllergy Clin Immunol (1990) 86(5):687-701. doi:10.1016/ S0091-6749(05)80170-8 of the results. All the authors reviewed the final version of the manuscript and agreed to its submission.

\section{ACKNOWLEDGMENTS}

The authors would like to thank Drs. Tara Sabo-Attwood, Song Liang, and Maureen Long for their scientific advice during the early stages of developing this manuscript. The authors would also like to thank Kristine Alpi for her help in optimizing the database search query. This research was supported with GG's discretionary funding at Duke University and through a grant from the National Institute of Allergy and Infectious Diseases (grant number R01-AI108993 to GG). The funders had no role in study design, data collection and interpretation, or the decision to submit the work for publication.

\section{SUPPLEMENTARY MATERIAL}

The Supplementary Material for this article can be found online at http://journal.frontiersin.org/article/10.3389/fvets.2017.00121/ full\#supplementary-material.

3. Jahangiri M, Neghab M, Nasiri G, Aghabeigi M, Khademian V, Rostami R, et al. Respiratory disorders associated with occupational inhalational exposure to bioaerosols among wastewater treatment workers of petrochemical complexes. Int J Occup Environ Med (2015) 6(1):41-9.

4. Lehtinen J, Tolvanen O, Nivukoski U, Veijanen A, Hanninen K. Occupational hygiene in terms of volatile organic compounds (VOCs) and bioaerosols 
at two solid waste management plants in Finland. Waste Manag (2013) 33(4):964-73. doi:10.1016/j.wasman.2012.11.010

5. Blais Lecours P, Veillette M, Marsolais D, Duchaine C. Characterization of bioaerosols from dairy barns: reconstructing the puzzle of occupational respiratory diseases by using molecular approaches. Appl Environ Microbiol (2012) 78(9):3242-8. doi:10.1128/AEM.07661-11

6. Tanner BD, Brooks JP, Gerba CP, Haas CN, Josephson KL, Pepper IL. Estimated occupational risk from bioaerosols generated during land application of class B biosolids. J Environ Qual (2008) 37(6):2311-21. doi:10.2134/jeq2007.0193

7. Douwes J, Thorne P, Pearce N, Heederik D. Bioaerosol health effects and exposure assessment: progress and prospects. Ann Occup Hyg (2003) 47(3):187-200. doi:10.1093/annhyg/meg032

8. Millner PD. Bioaerosols associated with animal production operations. Bioresour Technol (2009) 100(22):5379-85. doi:10.1016/j.biortech.2009. 03.026

9. Dungan RS, Leytem AB, Verwey SA, Bjorneberg DL. Assessment of bioaerosols at a concentrated dairy operation. Aerobiologia (2010) 26(3):171-84. doi:10.1007/s10453-010-9154-2

10. Just N, Kirychuk S, Gilbert Y, Letourneau V, Veillette M, Singh B, et al. Bacterial diversity characterization of bioaerosols from cage-housed and floor-housed poultry operations. Environ Res (2011) 111(4):492-8. doi:10.1016/j.envres.2011.01.009

11. Dungan RS, Leytem AB, Bjorneberg DL. Concentrations of airborne endotoxin and microorganisms at a 10,000-cow open-freestall dairy. J Anim Sci (2011) 89(10):3300-9. doi:10.2527/jas.2011-4002

12. Pearce RA, Sheridan JJ, Bolton DJ. Distribution of airborne microorganisms in commercial pork slaughter processes. Int J Food Microbiol (2006) 107(2):186-91. doi:10.1016/j.ijfoodmicro.2005.08.029

13. Shale K, Lues JFR, Venter P, Buys EM. The distribution of Staphylococci in bioaerosols from red-meat abattoirs. J Environ Health (2006) 69(4):25-32.

14. Shale K, Lues JFR. The etiology of bioaerosols in food environments. Food Rev Int (2007) 23(1):73-90. doi:10.1080/87559120600998205

15. Ziemer CJ, Bonner JM, Cole D, Vinje J, Constantini V, Goyal S, et al. Fate and transport of zoonotic, bacterial, viral, and parasitic pathogens during swine manure treatment, storage, and land application. J Anim Sci (2010) 88:E84-94. doi:10.2527/jas.2009-2331

16. Lues JFR, Theron MM, Venter P, Rasephei MHR. Microbial composition in bioaerosols of a high-throughput chicken-slaughtering facility. Poult Sci (2007) 86(1):142-9. doi:10.1093/ps/86.1.142

17. Venter P, Lues JFR, Theron H. Quantification of bioaerosols in automated chicken egg production plants. Poult Sci (2004) 83(7):1226-31. doi:10.1093/ ps/83.7.1226

18. Jonges M, van Leuken J, Wouters I, Koch G, Meijer A, Koopmans M. Wind-mediated spread of low-pathogenic avian influenza virus into the environment during outbreaks at commercial poultry farms. PLoS One (2015) 10(5):e0125401. doi:10.1371/journal.pone.0125401

19. Otake S, Dee SA, Jacobson L, Torremorell M, Pijoan C. Evaluation of aerosol transmission of porcine reproductive and respiratory syndrome virus under controlled field conditions. Vet Rec (2002) 150(26):804-8. doi:10.1136/vr.150.26.804

20. Butera M, Smith JH, Morrison WD, Hacker RR, Kains FA, Ogilvie JR. Concentration of respirable dust and bioaerosols and identification of certain microbial types in a hog-growing facility. Can J Anim Sci (1991) 71(2):271-7. doi:10.4141/cjas91-035

21. Thorne PS, Kiekhaefer MS, Whitten P, Donham KJ. Comparison of bioaerosol sampling methods in barns housing swine. Appl Environ Microbiol (1992) 58(8):2543-51.

22. Schwartz DA, Donham KJ, Olenchock SA, Popendorf WJ, Vanfossen DS, Burmeister LF, et al. Determinants of longitudinal changes in spirometric function among swine confinement operators and farmers. Am J Respir Crit Care Med (1995) 151(1):47-53. doi:10.1164/ajrccm.151.1.7812571

23. Lange JL, Thorne PS, Lynch N. Application of flow cytometry and fluorescent in situ hybridization for assessment of exposures to airborne bacteria. Appl Environ Microbiol (1997) 63(4):1557-63.

24. Thorne PS, Reynolds SJ, Milton DK, Bloebaum PD, Zhang X, Whitten P, et al. Field evaluation of endotoxin air sampling assay methods. Am Ind Hyg Assoc $J$ (1997) 58(11):792-9. doi:10.1080/15428119791012298

25. Torremorell M, Pijoan C, Janni K, Walker R, Joo HS. Airborne transmission of Actinobacillus pleuropneumoniae and porcine reproductive and respiratory syndrome virus in nursery pigs. Am J Vet Res (1997) 58(8):828-32.

26. Mackiewicz B. Study on exposure of pig farm workers to bioaerosols, immunologic reactivity and health effects. Ann Agric Environ Med (1998) 5(2):169-75.

27. Seedorf J, Hartung J, Schroder M, Linkert KH, Phillips VR, Holden MR, et al. Concentrations and emissions of airborne endotoxins and microorganisms in livestock buildings in Northern Europe. J Agric Eng Res (1998) 70(1):97-109. doi:10.1006/jaer.1997.0281

28. Duchaine C, Thorne PS, Meriaux A, Grimard Y, Whitten P, Cormier Y. Comparison of endotoxin exposure assessment by bioaerosol impinger and filter-sampling methods. Appl Environ Microbiol (2001) 67(6):2775-80. doi:10.1128/AEM.67.6.2775-2780.2001

29. Martens W, Martinec M, Zapirain R, Stark M, Hartung E, Palmgren U. Reduction potential of microbial, odour and ammonia emissions from a pig facility by biofilters. Int J Hyg Environ Health (2001) 203(4):335-45. doi:10.1078/1438-4639-00035

30. Predicala BZ, Maghirang RG, Jerez SB, Urban JE, Goodband RD. Dust and bioaerosol concentrations in two swine-finishing buildings in Kansas. Trans ASABE (2001) 44(5):1291-8. doi:10.13031/2013.6434

31. Szponar B, Larsson L. Use of mass spectrometry for characterising microbial communities in bioaerosols. Ann Agric Environ Med (2001) 8(2):111-7.

32. Predicala BZ, Urban JE, Maghirang RG, Jerez SB, Goodband RD. Assessment of bioaerosols in swine barns by filtration and impaction. Curr Microbiol (2002) 44(2):136-40. doi:10.1007/s00284-001-0064-y

33. Adhikari A, Reponen T, Lee SA, Grinshpun SA. Assessment of human exposure to airborne fungi in agricultural confinements: personal inhalable sampling versus stationary sampling. Ann Agric Environ Med (2004) 11(2):269-77.

34. Agranovski V, Ristovski Z, Blackall PJ, Morawska L. Size-selective assessment of airborne particles in swine confinement building with the UVAPS. Atmos Environ (2004) 38(23):3893-901. doi:10.1016/j.atmosenv.2004.02.058

35. Gibbs SG, Green CF, Tarwater PM, Scarpino PV. Airborne antibiotic resistant and nonresistant bacteria and fungi recovered from two swine herd confined animal feeding operations. JOccup Environ Hyg (2004) 1(11):699-706. doi:10.1080/15459620490515824

36. Chi MC, Li CS. Fluorochrome and fluorescent in situ hybridization to monitor bioaerosols in swine buildings. Aerosol Sci Technol (2005) 39(11):1101-10. doi:10.1080/02786820500421539

37. Chinivasagam HN, Blackall PJ. Investigation and application of methods for enumerating heterotrophs and Escherichia coli in the air within piggery sheds. J ApplMicrobiol(2005) 98(5):1137-45. doi:10.1111/j.1365-2672.2005.02560.x

38. Jo W-K, Kang J-H. Exposure levels of airborne bacteria and fungi in Korean swine and poultry sheds. Arch Environ Occup Health (2005) 60(3):140-6. doi:10.3200/AEOH.60.3.140-146

39. Karwowska E. Microbiological air contamination in farming environment. Pol J Environ Stud (2005) 14(4):445-9.

40. Gibbs SG, Green CF, Tarwater PM, Mota LC, Mena KD, Scarpino PV. Isolation of antibiotic-resistant bacteria from the air plume downwind of a swine confined or concentrated animal feeding operation. Environ Health Perspect (2006) 114(7):1032-7. doi:10.1289/ehp.8910

41. Green CF, Gibbs SG, Tarwater PM, Mota LC, Scarpino PV. Bacterial plume emanating from the air surrounding swine confinement operations. J Occup Environ Hyg (2006) 3(1):9-15. doi:10.1080/15459620500430615

42. Lee SA, Adhikari A, Grinshpun SA, McKay R, Shukla R, Reponen T. Personal exposure to airborne dust and microorganisms in agricultural environments. J Occup Environ Hyg (2006) 3(3):118-30. doi:10.1080/15459620500524607

43. Kim KY, Ko HJ, Kim HT, Kim YS, Roh YM, Lee CM, et al. Monitoring of aerial pollutants emitted from swine houses in Korea. Environ Monit Assess (2007) 133(1-3):255-66. doi:10.1007/s10661-006-9578-x

44. Kim KY, Ko HJ, Kim HT, Kim YS, Roh YM, Lee CM, et al. Influence of extreme seasons on airborne pollutant levels in a pig-confinement building. Arch Environ Occup Health (2007) 62(1):27-32. doi:10.3200/AEOH.62.1.27-32

45. Ko G, Simmons OD III, Likirdopulos CA, Worley-Davis L, Williams M, Sobsey MD. Investigation of bioaerosols released from swine farms using conventional and alternative waste treatment and management technologies. Environ Sci Technol (2008) 42(23):8849-57. doi:10.1021/es801091t

46. Nehme B, Letourneau V, Forster RJ, Veillette M, Duchaine C. Cultureindependent approach of the bacterial bioaerosol diversity in the standard 
swine confinement buildings, and assessment of the seasonal effect. Environ Microbiol (2008) 10(3):665-75. doi:10.1111/j.1462-2920.2007.01489.x

47. Dee S, Otake S, Oliveira S, Deen J. Evidence of long distance airborne transport of porcine reproductive and respiratory syndrome virus and $\mathrm{Myco}-$ plasma hyopneumoniae. Vet Res (2009) 40(4):39. doi:10.1051/vetres/2009022

48. Lavoie J, Godbout S, Lemay SP, Belzile M. Impact of in-barn manure separation on biological air quality in an experimental setup identical to that in swine buildings. J Agric Saf Health (2009) 15(3):225-40. doi:10.13031/ 2013.27407

49. Nehme B, Gilbert Y, Letourneau V, Forster RJ, Veillette M, Villemur R, et al. Culture-independent characterization of archaeal biodiversity in swine confinement building bioaerosols. Appl Environ Microbiol (2009) 75(17):5445-50. doi:10.1128/AEM.00726-09

50. Pitkin A, Deen J, Dee S. Use of a production region model to assess the airborne spread of porcine reproductive and respiratory syndrome virus. Vet Microbiol (2009) 136(1-2):1-7. doi:10.1016/j.vetmic.2008.10.013

51. Thorne PS, Ansley AC, Perry SS. Concentrations of bioaerosols, odors, and hydrogen sulfide inside and downwind from two types of swine livestock operations. JOccup Environ Hyg (2009) 6(4):211-20. doi:10.1080/15459620902729184

52. Ko G, Simmons OD III, Likirdopulos CA, Worley-Davis L, Williams CM, Sobsey MD. Endotoxin levels at swine farms using different waste treatment and management technologies. Environ Sci Technol (2010) 44(9):3442-8. doi:10.1021/es9026024

53. Letourneau V, Nehme B, Meriaux A, Masse D, Cormier Y, Duchaine C. Human pathogens and tetracycline-resistant bacteria in bioaerosols of swine confinement buildings and in nasal flora of hog producers. Int $J$ Hyg Environ Health (2010) 213(6):444-9. doi:10.1016/j.ijheh.2010.09.008

54. Letourneau V, Nehme B, Meriaux A, Masse D, Duchaine C. Impact of production systems on swine confinement buildings bioaerosols. J Occup Environ Hyg (2010) 7(2):94-102. doi:10.1080/15459620903425642

55. Otake S, Dee S, Corzo C, Oliveira S, Deen J. Long-distance airborne transport of infectious PRRSV and Mycoplasma hyopneumoniae from a swine population infected with multiple viral variants. Vet Microbiol (2010) 145(3-4):198-208. doi:10.1016/j.vetmic.2010.03.028

56. Verreault D, Letourneau V, Gendron L, Masse D, Gagnon CA, Duchaine C. Airborne porcine porcine circovirus in Canadian swine confinement buildings. Vet Microbiol (2010) 141(3-4):224-30. doi:10.1016/j.vetmic.2009.09.013

57. Keessen EC, Donswijk CJ, Hol SP, Hermanus C, Kuijper EJ, Lipman LJA. Aerial dissemination of Clostridium difficile on a pig farm and its environment. Environ Res (2011) 111(8):1027-32. doi:10.1016/j.envres.2011.09.014

58. Cyprowski M, Buczynska A, Kozajda A, Sowiak M, Brodka K, SzadkowskaStanczyk I. Exposure to (1 ->3)-beta-D-glucans in swine farms. Aerobiologia (2012) 28(2):161-8. doi:10.1007/s10453-011-9220-4

59. Hong P-Y, Li X, Yang X, Shinkai T, Zhang Y, Wang X, et al. Monitoring airborne biotic contaminants in the indoor environment of pig and poultry confinement buildings. Environ Microbiol (2012) 14(6):1420-31. doi:10.1111/j.1462-2920.2012.02726.x

60. Kristiansen A, Saunders AM, Hansen AA, Nielsen PH, Nielsen JL. Community structure of bacteria and fungi in aerosols of a pig confinement building. FEMS Microbiol Ecol (2012) 80(2):390-401. doi:10.1111/j.1574-6941.2012.01305.x

61. Linhares DCL, Cano JP, Wetzell T, Nerem J, Torremorell M, Dee SA. Effect of modified-live porcine reproductive and respiratory syndrome virus (PRRSv) vaccine on the shedding of wild-type virus from an infected population of growing pigs. Vaccine (2012) 30(2):407-13. doi:10.1016/j.vaccine.2011.10.075

62. Sowiak M, Brodka K, Buczynska A, Cyprowski M, Kozajda A, Sobala W, et al. An assessment of potential exposure to bioaerosols among swine farm workers with particular reference to airborne microorganisms in the respirable fraction under various breeding conditions. Aerobiologia (2012) 28(2):121-33. doi:10.1007/s10453-011-9216-0

63. Corzo CA, Culhane M, Dee S, Morrison RB, Torremorell M. Airborne detection and quantification of swine influenza a virus in air samples collected inside, outside and downwind from swine barns. PLoS One (2013) 8(8):e71444. doi:10.1371/journal.pone.0071444

64. Corzo CA, Romagosa A, Dee SA, Gramer MR, Morrison RB, Torremorell M. Relationship between airborne detection of influenza A virus and the number of infected pigs. Vet $J$ (2013) 196(2):171-5. doi:10.1016/j.tvjl.2012.09.024

65. de Evgrafov MR, Koll P, Frank DN, Baumgartner LK, Robertson CE, Hernandez MT, et al. Molecular analysis of bacterial and circovirus bioaerosols in concentrated animal feeding operations. Aerosol Sci Technol (2013) 47(7):755-66. doi:10.1080/02786826.2013.789477

66. Masclaux FG, Sakwinska O, Charriere N, Semaani E, Oppliger A. Concentration of airborne Staphylococcus aureus (MRSA and MSSA), total bacteria, and endotoxins in pig farms. Ann Occup Hyg (2013) 57(5):550-7. doi:10.1093/annhyg/mes098

67. Pavilonis BT, O’Shaughnessy PT, Altmaier R, Metwali N, Thorne PS. Passive monitors to measure hydrogen sulfide near concentrated animal feeding operations. Environ Sci Process Impacts (2013) 15(6):1271-8. doi:10.1039/ c3em00082f

68. Viegas S, Veiga L, Figueredo P, Almeida A, Carolino E, Sabino R, et al. Occupational exposure to aflatoxin B-1 in swine production and possible contamination sources. J Toxicol Environ Health (2013) 76(15):944-51. doi:10.1080/15287394.2013.826569

69. Yang X, Wang X, Zhang Y, Lee J, Su J, Gates RS. Monitoring total endotoxin and $(1->3)$-beta-D-glucan at the air exhaust of concentrated animal feeding operations. J Air Waste Manag Assoc (2013) 63(10):1190-8. doi:10.1080/109 62247.2013.810556

70. Agerso Y, Vigre H, Cavaco LM, Josefsen MH. Comparison of air samples, nasal swabs, ear-skin swabs and environmental dust samples for detection of methicillin-resistant Staphylococcus aureus (MRSA) in pig herds. Epidemiol Infect (2014) 142(8):1727-36. doi:10.1017/S095026881300280X

71. Alonso C, Goede DP, Morrison RB, Davies PR, Rovira A, Marthaler DG, et al. Evidence of infectivity of airborne porcine epidemic diarrhea virus and detection of airborne viral RNA at long distances from infected herds. Vet Res (2014) 45:73. doi:10.1186/s13567-014-0073-z

72. Andersen KB, Glasius M, Feilberg A. Gas-particle partitioning of odorants in a pig house measured by thermal desorption GC/MS. Environ Sci Process Impacts (2014) 16(5):1059-68. doi:10.1039/c3em00444a

73. Bonifait L, Veillette M, Letourneau V, Grenier D, Duchaine C. Detection of Streptococcus suis in bioaerosols of swine confinement buildings. Appl Environ Microbiol (2014) 80(11):3296-304. doi:10.1128/AEM. 04167-13

74. Brito B, Dee S, Wayne S, Alvarez J, Perez A. Genetic diversity of PRRS virus collected from air samples in four different regions of concentrated swine production during a high incidence season. Viruses (2014) 6(11):4424-36. doi:10.3390/v6114424

75. Corzo CA, Allerson M, Gramer M, Morrison RB, Torremorell M. Detection of airborne influenza a virus in experimentally infected pigs with maternally derived antibodies. Transbound Emerg Dis (2014) 61(1):28-36. doi:10.1111/j.1865-1682.2012.01367.x

76. Damte D, Yohanes SB, Hossain MA, Lee S-J, Rhee M-H, Kim Y-H, et al. Detection of naturally aerosolized Mycoplasma hyopneumoniae from the air of selected swine farms. Aerobiologia (2014) 30(2):205-9. doi:10.1007/ s10453-013-9315-1

77. Kumari P, Choi HL. Seasonal variability in airborne biotic contaminants in swine confinement buildings. PLoS One (2014) 9(11):e112897. doi:10.1371/ journal.pone.0112897

78. Lee S-A, Liao C-H. Size-selective assessment of agricultural workers' personal exposure to airborne fungi and fungal fragments. Sci Total Environ (2014) 466:725-32. doi:10.1016/j.scitotenv.2013.07.104

79. Van Ransbeeck N, Van Langenhove H, Michiels A, Sonck B, Demeyer P. Exposure levels of farmers and veterinarians to particulate matter and gases during operational tasks in pig-fattening houses. Ann Agric Environ Med (2014) 21(3):472-8. doi:10.5604/12321966.1120586

80. Alonso C, Raynor PC, Davies PR, Torremorell M. Concentration, size distribution, and infectivity of airborne particles carrying swine viruses. PLoS One (2015) 10(8):e0135675. doi:10.1371/journal.pone.0135675

81. Arfken AM, Song B, Sung J-S. Comparison of airborne bacterial communities from a hog farm and spray field. J Microbiol Biotechnol (2015) 25(5):709-17. doi:10.4014/jmb.1408.08005

82. Choi MJ, Torremorell M, Bender JB, Smith K, Boxrud D, Ertl JR, et al. Live animal markets in Minnesota: a potential source for emergence of novel influenza A viruses and interspecies transmission. Clin Infect Dis (2015) 61(9):1355-62. doi:10.1093/cid/civ618

83. Kumari P, Choi HL. Manure removal system influences the abundance and composition of airborne biotic contaminants in swine confinement buildings. Environ Monit Assess (2015) 187(8):537. doi:10.1007/ s10661-015-4759-0 
84. Wang CH, Chen BT, Han BC, Liu AC, Hung PC, Chen CY, et al. Field evaluation of personal sampling methods for multiple bioaerosols. PLoS One (2015) 10(3):e0120308. doi:10.1371/journal.pone.0120308

85. Anderson BD, Ma M, Xia Y, Wang T, Shu B, Lednicky JA, et al. Bioaerosol sampling in modern agriculture: a novel approach for emerging pathogen surveillance? J Infect Dis (2016) 214(4):537-45. doi:10.1093/infdis/jiw180

86. Ferguson DD, Smith TC, Hanson BM, Wardyn SE, Donham KJ. Detection of airborne methicillin-resistant Staphylococcus aureus inside and downwind of a swine building, and in animal feed: potential occupational, animal health, and environmental implications. J Agromedicine (2016) 21(2):149-53. doi:10.1080/1059924X.2016.1142917

87. Neira V, Rabinowitz P, Rendahl A, Paccha B, Gibbs SG, Torremorell M. Characterization of viral load, viability and persistence of influenza a virus in air and on surfaces of swine production facilities. PLoS One (2016) 11(1):e0146616. doi:10.1371/journal.pone.0146616

88. O’Brien KM, Nonnenmann MW. Airborne influenza A is detected in the personal breathing zone of swine veterinarians. PLoS One (2016) 11(2):e0149083. doi:10.1371/journal.pone.0149083

89. Roque K, Lim GD, Jo JH, Shin KM, Song ES, Gautam R, et al. Epizootiological characteristics of viable bacteria and fungi in indoor air from porcine, chicken, or bovine husbandry confinement buildings. J Vet Sci (2016) 17(4):531-8. doi:10.4142/jvs.2016.17.4.531

90. Alonso C, Raynor PC, Goyal S, Olson BA, Alba A, Davies PR, et al. Assessment of air sampling methods and size distribution of virus-laden aerosols in outbreaks in swine and poultry farms. J Vet Diagn Invest (2017) 29(3):298-304. doi:10.1177/1040638717700221

91. Walser SM, Brenner B, Wunderlich A, Tuschak C, Huber S, Kolb S, et al. Detection of Legionella-contaminated aerosols in the vicinity of a bio-trickling filter of a breeding sow facility - a pilot study. Sci Total Environ (2017) 575:1197-202. doi:10.1016/j.scitotenv.2016.09.191

92. Hermann JR, Hoff SJ, Yoon KJ, Burkhardt AC, Evans RB, Zimmerman JJ. Optimization of a sampling system for recovery and detection of airborne porcine reproductive and respiratory syndrome virus and swine influenza virus. Appl Environ Microbiol (2006) 72(7):4811-8. doi:10.1128/AEM.00472-06

93. Zuo Z, Kuehn TH, Verma H, Kumar S, Goyal SM, Appert J, et al. Association of airborne virus infectivity and survivability with its carrier particle size. Aerosol Sci Technol (2013) 47(4):373-82. doi:10.1080/02786 826.2012.754841

94. Grinshpun SA, Willeke K, Ulevicius V, Juozaitis A, Terzieva S, Donnelly J, et al. Effect of impaction, bounce and reaerosolization on the collection efficiency of impingers. Aerosol Sci Technol (1997) 26(4):326-42. doi:10.1080/02786829708965434

95. Willeke K, Lin XJ, Grinshpun SA. Improved aerosol collection by combined impaction and centrifugal motion. Aerosol Sci Technol (1998) 28(5):439-56. doi:10.1080/02786829808965536

96. Hogan CJ Jr, Kettleson EM, Lee MH, Ramaswami B, Angenent LT, Biswas P. Sampling methodologies and dosage assessment techniques for submicrometre and ultrafine virus aerosol particles. J Appl Microbiol (2005) 99(6):1422-34. doi:10.1111/j.1365-2672.2005.02720.x

97. Pan M, Eiguren-Fernandez A, Hsieh H, Afshar-Mohajer N, Hering SV, Lednicky J, et al. Efficient collection of viable virus aerosol through laminar-flow, water-based condensational particle growth. J Appl Microbiol (2016) 120(3):805-15. doi:10.1111/jam.13051

98. Lednicky J, Pan MH, Loeb J, Hsieh H, Eiguren-Fernandez A, Hering S, et al. Highly efficient collection of infectious pandemic influenza H1N1 virus (2009) through laminar-flow water based condensation. Aerosol Sci Technol (2016) 50(7):I-IV. doi:10.1080/02786826.2016.1179254

99. Jhung MA, Nelson DI; Centers for Disease Control and Prevention (CDC). Outbreaks of avian influenza A (H5N2), (H5N8), and (H5N1) among birds United States, December 2014-January 2015. MMWR Morb Mortal Wkly Rep (2015) 64(4):111. doi:10.3201/eid2112.150904

100. Torremorell M, Alonso C, Davies PR, Raynor PC, Patnayak D, Torchetti M, et al. Investigation into the airborne dissemination of H5N2 highly pathogenic avian influenza virus during the 2015 spring outbreaks in the Midwestern United States. Avian Dis (2016) 60(3):637-43. doi:10.1637/11395021816-Reg.1

101. Centers for Disease Control and Prevention (CDC). Influenza A (H3N2) variant virus-related hospitalizations: Ohio, 2012. MMWR Morb Mortal Wkly Rep (2012) 61:764-7.

Conflict of Interest Statement: The authors declare that the research was conducted in the absence of any commercial or financial relationships that could be construed as a potential conflict of interest.

Copyright (C) 2017 Anderson, Lednicky, Torremorell and Gray. This is an open-access article distributed under the terms of the Creative Commons Attribution License (CC BY). The use, distribution or reproduction in other forums is permitted, provided the original author(s) or licensor are credited and that the original publication in this journal is cited, in accordance with accepted academic practice. No use, distribution or reproduction is permitted which does not comply with these terms. 